\title{
Characterization of local chickens (Gallus gallus domesticus) in Shelleng and Song Local Government Areas of Adamawa State, Nigeria
}

\author{
A.A. Apuno*, Mbap,S.T. and T. Ibrahim** \\ Animal Production Programme Abubakar Tafawa Balewa University \\ P.M.B.0248, Bauchi, \\ *Dept of Agric.and Natural Res. Shelleng L.G.A. Adamawa State, Nigeria \\ **Email:tahibatta@yahoo.com
}

\begin{abstract}
This study was conducted in Song and Shelleng local government areas of Adamawa State, between January 2004 and December 2006, to determine some characteristics of local chickens. A total of 451 chickens of both sexes were examined. About $49 \%$ of the birds observed were males while $51 \%$ were females. The comb type was mostly single $(96.45 \%)$. Eye colours were either dark brown $(37.92 \%)$, light brown $(28.82 \%)$, dark red $(28.60 \%)$, light green $(2.00 \%)$, pink $(1.33 \%)$ or dark ash $(1.33 \%)$. For plumage colour, $17.07 \%$ of the chickens were classified as black and mottled, $14.41 \%$ as dark red/golden, $13.97 \%$ as dark brown, $12.64 \%$ as brown and mottled while 9.76, 6.85, 6.86 and 6.21 were classified as ash, white, white and mottled, and black, respectively. Most chickens (38.8\%) had pink shanks, while $23.28 \%, 16.63 \%$ and $12.42 \%$ had dark ash, ash ,and light yellow shanks, respectively. The remaining birds (8.87\%) had either milky, red, light pink or ash and yellow shanks. Average live weight, body girth, body length and shank length were $1.3 \mathrm{~kg}, 27.59 \mathrm{~cm}, 18.23 \mathrm{~cm}$ and $8.72 \mathrm{~cm}$, respectively. About $40.47 \%$ of the eggs observed were light brown. The average clutch size, egg weight, egg length, egg width, shell weight and shell thickness were $7.86,39.03 \mathrm{~g}, 4.52 \mathrm{~cm}, 3.16 \mathrm{~cm}, 3.80 \mathrm{~g}$ and $0.53 \mathrm{~mm}$ respectively. Generally, the local chickens in the study area were mostly black and mottled with dark brown eyes and pink shanks, and mostly lay light brown eggs. There were also distinctive differences in almost all the measurable parameters. These distinctions provide the basis for which they could be classified into breeds.
\end{abstract}

Keywords : characterization, chickens, plumage, body weight, egg size

\section{INTRODUCTION}

Chickens in developing countries provide nutrition for the family, a small cash flow reserve for times of celebrations or need and in some areas contribute to religious ceremonies and recreation (Roberts, 1995). Scavenger chickens are usually self-reliant and hardy, capable of withstanding the abuses of harsh climate, minimal management, and inadequate nutrition. They live largely on weed seeds, insects, and feeds that would otherwise be a waste (Vietmeyer et al., 1991). To the world's poor, chickens are probably the most nutritionally important domestic animal species.

In 1980, the then Gongola state of Nigeria was estimated to have 9.3 million chickens- about $6.2 \%$ of the total chicken population in the country- with an average of 10.4 local chickens per household (Ekeren et al., 1990). Adamawa state carved out of Gongola state is one of the principal livestock producing states of Nigeria. The state ministry of
Agriculture livestock census figure of 1991 showed that the state had 2.0 million poultry (Aliyara and Yakubu, 2000) most of which were uncharacterized indigenous ecotypes.

Although concerted efforts at genetic improvement of the Nigerian livestock and birds had since started (Mbap, 1985), most previous efforts like in other countries concentrated on genetic improvement through crossbreeding with exotic breeds (Katule, 1990; Kitalyi, 1998; Gueye and Hooft, 2002). The result was poor; partly because very little was known about their genetic make up (Msoffe et al., 2004). Mbap (1985) suggested that before attempting any genetic improvement, animals must first be characterized. This study was therefore intended to characterize indigenous chickens for specialized production of lines for selection purposes

\section{MATERIALS AND METHODS}

This study was conducted in Song and Shelleng local government areas of Adamawa State, from January 
2004 to December,2006 .The tropical climate of the state as described by Gambo (2002) has rainy season which commences from April and ends in October. The average monthly rainfall for the state during the wet season is $79 \mathrm{~mm}$ in the northern and $101 \mathrm{~mm}$ in the southern parts. The average minimum temperature is $15.2^{\circ} \mathrm{C}$ and the maximum is $39.70^{\circ} \mathrm{C}$. The location of Shelleng Local Government area (about $111 \mathrm{~km}$ south of the state capital) has been described (Chimbekujwo et al., 2006) as lying between latitude $09^{\circ} 49^{\prime}-10^{\circ} 4$ and longitude $12^{\circ} 37^{\circ}$. $13 \mathrm{E}$. It has an average altitude of $216.44 \mathrm{~m}$ above sea level. It shares border in the north with Borno state; west, Guyuk; south, Demsa; northeast, Gombi and southeast Song Local Government Areas of Adamawa State. Song Local Government Area (about $74 \mathrm{~km}$ east of the state capital) lies between latitude $09^{\circ} 53^{\circ}$ and $10^{\circ} 12 \mathrm{~N}$ and longitude 12 and $1217 \mathrm{E}$. It has an average altitude of $367.50 \mathrm{~m}$ above sea level.

Data were collected on 451 adult local chickens and 525 eggs. The birds, which comprised 222 males and 229 females, were obtained from ten randomly sampled communities in Song Local Government Area namely; Song, Bakka, Wuro-Daudu, Wuro- De, Modungo, Bolki, Gyawan, Hombo, Sigire, Gudu and Shelleng metropolis in Shelleng Local Government Area. Birds were individually observed for phenotype expression (plumage, eye and shank colours and comb type). The body size parameters measured included body weight, body girth (the circumference of the breast region), body length (distance from the beginning of the neck to the tail) and shank length (length of the tarso-metatarsus from the hock joint to the metatarsal pad). Egg colour and other egg measurements including egg weight, width and length, shell thickness and weight were also observed. Egg length was taken as the distance from one end to the other. Egg width was determined at the widest diameter. Body and shank lengths were measured using a graduated wooden ruler while body girth was determined using a graduated tape. Body weight was measured in kilogram using a "SALTER" P11640/9 (model 235 65; 25kg x 100g) hanging scale. Egg length and width were measured using a vernier calliper while shell thickness was measured using a micrometer screw gauge. Egg and shell weight however were measured using a digital electrical navigator "ohaus" (D110 Max: 4100g) balance.
Chi-square analysis was employed to test the differences between proportions within subclasses. Analysis of variance was carried out on measurable parameters using the non measurable parameters as the main factors. Correlation coefficients were also determined between measurable body and egg parameters. The Statistical Package for Social Sciences (SPSS, 1996) was utilized for these analyses.

\section{RESULTS}

Table 1 shows percentage of some body and egg characteristics in chickens in the study area. Of the 451 chickens observed, $50.78 \%$ were females while $49.22 \%$ were males. There were significant $(P<0.01)$ differences in rate of occurrence of comb types. The Single comb was the commonest $(96.45 \%)$, followed by rose $(3.10 \%)$ while pea was the least $(0.44 \%)$.Similarly, significant $(p<0.01)$ differences existed in percentage occurrence of eye colour. Dark brown colour was the most (37.92\%) prominent, whereas pink and dark ash with same frequencies $(1.33 \%)$ were the least. Significant $(P<0.01)$ variations also existed among plumage colours. The black and mottled with the frequency of $17.07 \%$ was the most common, while the white and mottled and black plumage colours were least with frequencies of $6.86 \%$ and $6.21 \%$, respectively. In terms of shank color, the proportions also differed pronouncedly $(P<0.01)$. Chickens with pink shanks accounted for the largest $(38.80 \%)$, while those having red shanks only accounted for less than $1 \%$. In the same vain, considerable $(p<0.01)$ differences were detected among the birds in the color of eggs laid, light brown colour being the most common $(40.47 \%)$, followed by white $(35.45 \%)$ while brown eggs were the least $(24.08 \%)$.

The means and standard errors of some body and egg measurements are shown in Table 2. Year did not have significant effect on any body or egg measurement observed in the study area. The effect of location on live weight, body length and egg weight however was significant $(P<0.01)$. Modungo community had the heaviest $(1.53 \mathrm{~kg})$ chickens while Gyawan had the lightest $(1.13 \mathrm{~kg})$. Chickens in Shelleng, Bolki and Song had the lengthiest $(19.50 \mathrm{~cm}, \quad 19.23 \mathrm{~cm}$ and $18.96 \mathrm{~cm}$ respectively) bodies, whereas shortest $(17.71 \mathrm{~cm})$ chickens were found in Bakka. On the other hand, Bolki had the heaviest $(58.33 \mathrm{~g})$ eggs while Modungo recorded the lightest $(24.09 \mathrm{~g})$. Season had significant $(P<0.05)$ effect on clutch size and body girth. More eggs were 
laid during late wet than during early dry or early wet seasons. Sex was also shown to have significant influence on body length and shank length $(p<0.001)$ and live weight $(p<0.05)$.

Plumage colour was found to have significant effect on body girth $(p<0.05)$, shank length $(P<0.05)$ and body length $(p<0.001)$. The black plus mottled had the highest $(28.45 \mathrm{~cm})$ body girth while chickens with Table 1: Percentage of some body and egg characteristics

\begin{tabular}{|c|c|c|c|c|}
\hline Trait & Category & No & Percentage & $\underline{x}^{2}$ \\
\hline \multirow[t]{2}{*}{ Sex } & Male & 222 & 49.22 & \\
\hline & Female & 229 & 50.78 & $0.109^{\mathrm{ns}}$ \\
\hline \multirow[t]{9}{*}{ Plumage colour } & Black and mottled & 77 & 17.07 & \\
\hline & White and mottled & 31 & 6.87 & \\
\hline & Brown and mottled & 57 & 12.64 & \\
\hline & Black & 28 & 6.21 & \\
\hline & White & 39 & 8.65 & \\
\hline & Brown & 47 & 10.42 & \\
\hline & Dark brown & 63 & 13.97 & \\
\hline & Dark red/golden & 65 & 14.41 & \\
\hline & Ash & 44 & 9.76 & $43.57^{\star *}$ \\
\hline \multirow[t]{6}{*}{ Eye colour } & Dark red & 129 & 28.60 & \\
\hline & Dark brown & 171 & 37.92 & \\
\hline & Pink & 6 & 1.33 & \\
\hline & Light brown & 130 & 28.82 & \\
\hline & Light green & 9 & 2.00 & \\
\hline & Dark ash & 6 & 1.33 & $386.26^{* *}$ \\
\hline \multirow[t]{9}{*}{ Shank colour } & Milky & 5 & 1.11 & \\
\hline & Dark ash & 105 & 23.28 & \\
\hline & Ash & 75 & 16.63 & \\
\hline & Red & 4 & 0.89 & \\
\hline & Light pink & 8 & 1.77 & \\
\hline & Light yellow & 56 & 12.42 & \\
\hline & Pink & 175 & 38.80 & \\
\hline & Ash and yellow & 6 & 1.33 & \\
\hline & Yellow & 17 & 3.77 & $563.59 * *$ \\
\hline \multirow[t]{3}{*}{ Comb type } & Single & 435 & 96.45 & \\
\hline & Rose & 14 & 3.10 & \\
\hline & Pea & 2 & 0.44 & $809.05^{* *}$ \\
\hline \multirow[t]{3}{*}{ Egg colour } & Brown & 72 & 24.08 & \\
\hline & White & 106 & 35.45 & \\
\hline & Light brown & 121 & 40.47 & $12.65^{\text {*n }}$ \\
\hline
\end{tabular}

$\mathrm{X}^{2}=$ chi squared $\mathrm{ns}=$ not significant ${ }^{*}=$ significant @ $0.05{ }^{* *}=$ significant $@ 0.01$ ash plumage had the lowest $(25.82 \mathrm{~cm})$ body girth. Shank and body lengths of $9.65 \mathrm{~cm}$ and $19.34 \mathrm{~cm}$ respectively in dark red (golden) chickens were longest, whereas $8.05 \mathrm{~cm}$ for shank and $17.48 \mathrm{~cm}$ for body lengths recorded for those having brown plumage had the shortest values for these measurements. 
Table 2: means and standard errors of body and egg measurement

\begin{tabular}{|c|c|c|c|c|c|c|c|}
\hline Factor & & LW (kg) & BGirt (cm) & BL(cm) & SHKL(cm) & CLuS(No) & Egg WT(g) \\
\hline Year & & $\bar{X}$ ns SE & $\bar{X}$ ns $S E$ & $\bar{X}$ ns $\quad$ SE & $\overline{\mathrm{X}}$ ns $\mathrm{SE}$ & $\bar{X}$ ns SE & $\bar{X}$ ns $S E$ \\
\hline & 2004 & 1.110 .03 & 34.890 .57 & 19.580 .34 & 7.430 .35 & 7.630 .31 & $\begin{array}{ll}31.0 & 0.01\end{array}$ \\
\hline & 2005 & $1.30 \quad 0.04$ & 27.800 .39 & $18.60 \quad 0.19$ & $\begin{array}{ll}8.43 & 0.12 \\
\end{array}$ & $\begin{array}{lll}9.08 & 0.49\end{array}$ & $\begin{array}{ll}42.7 & 0.39\end{array}$ \\
\hline & 2006 & 1.300 .03 & 26.650 .19 & 18.040 .11 & $8.93 \quad 0.07$ & 7.320 .25 & 32.40 .19 \\
\hline \multirow[t]{12}{*}{ Location } & & $* *$ & ns & $* *$ & ns & Ns & $* *$ \\
\hline & Shelleng & $1.20^{\mathrm{b}} 0.05$ & 34.650 .64 & $19.52^{\mathrm{a}} 0.33$ & $\begin{array}{lll}7.60 & 0.32 \\
\end{array}$ & $7.62 \quad 0.30$ & $31.00^{\mathrm{ab}} 0.01$ \\
\hline & Gyawan & $1.13^{\mathrm{b}} 0.05$ & 26.670 .73 & $18.70^{\mathrm{ab}} 0.44$ & 8.200 .22 & $9.92 \quad 0.16$ & $37.08^{\mathrm{ab}} 0.04$ \\
\hline & W/Daudu & $1.26^{\mathrm{b}} 0.11$ & 27.241 .00 & $18.29^{\mathrm{ab}} 0.48$ & $\begin{array}{lll}8.07 & 0.24 \\
\end{array}$ & $\begin{array}{lll}8.71 & 0.58 \\
\end{array}$ & $35.36^{\mathrm{ab}} 0.03$ \\
\hline & Gudu & $1.35^{\mathrm{b}} 0.08$ & 28.560 .53 & $18.88^{\mathrm{ab}} 0.37$ & $\begin{array}{ll}8.07 & 0.24\end{array}$ & 10.001 .32 & $44.36^{\mathrm{ab}} 0.04$ \\
\hline & Wurode & $1.25^{\mathrm{b}} 0.06$ & 27.290 .61 & $18.42^{\mathrm{ab}} 0.30$ & $\begin{array}{ll}8.63 & 0.26\end{array}$ & 8.251 .07 & $56.69^{\mathrm{ab}} 0.21$ \\
\hline & Hombo & $1.34^{\mathrm{b}} 0.17$ & 27.030 .52 & $17.79^{\mathrm{ab}} 0.54$ & $9.34 \quad 0.34$ & $\begin{array}{ll}6.31 & 0.90 \\
\end{array}$ & $27.31^{b} 0.03$ \\
\hline & Bolki & $1.32^{\mathrm{b}} 0.09$ & 27.230 .61 & $19.23^{\mathrm{a}} 0.64$ & 9.430 .40 & 6.831 .54 & $58.33^{\mathrm{a}} 0.29$ \\
\hline & Singire & $1.27^{\mathrm{b}} 0.06$ & $26.50 \quad 0.60$ & $18.50^{\mathrm{ab}} 0.38$ & 9.170 .18 & 5.331 .08 & $26.67^{\mathrm{b}} 0.03$ \\
\hline & Madungo & $1.53^{\mathrm{a}} 0.28$ & 26.240 .55 & $18.44^{\text {ab }} 0.28$ & $\begin{array}{ll}9.30 & 0.25\end{array}$ & 6.000 .80 & $24.09^{b} 0.03$ \\
\hline & Song & $1.21^{\mathrm{b}} 0.05$ & 26.560 .58 & $18.96^{\mathrm{a}} 0.21$ & $9.00 \quad 0.19$ & 7.440 .63 & $30.61^{\mathrm{ab}} 0.02$ \\
\hline & Bakka & $1.23^{\mathrm{b}} 0.02$ & 26.630 .27 & $17.71^{\mathrm{b}} 0.13$ & $\begin{array}{lll}8.74 & 0.08 \\
\end{array}$ & $\begin{array}{ll}7.78 & 0.31 \\
\end{array}$ & $33.21^{\mathrm{ab}} 0.01$ \\
\hline \multirow[t]{4}{*}{ Season } & & Ns & $*$ & Ns & ns & $*$ & ns \\
\hline & Early dry & 1.260 .02 & 27.170 .20 & 18.160 .10 & 8.800 .06 & $7.60^{\mathrm{b}} 0.22$ & 32.80 .01 \\
\hline & Early wet & $\begin{array}{ll}1.31 & 0.13\end{array}$ & 26.711 .80 & 17.940 .52 & $\begin{array}{ll}8.03 & 0.24 \\
\end{array}$ & $7.67^{\mathrm{b}} 0.76$ & 34.20 .04 \\
\hline & Late wet & 1.300 .05 & $27.92 \quad 0.44$ & 18.760 .26 & $8.80 \quad 0.19$ & $9.35^{\mathrm{a}} 0.99$ & 54.30 .15 \\
\hline \multirow[t]{4}{*}{ Sex } & & $*$ & ns & $* * *$ & $* * *$ & Ns & ns \\
\hline & Male & 1.340 .04 & 27.590 .26 & 18.630 .14 & 9.690 .07 & - & - \\
\hline & Female & 1.180 .03 & 26.850 .26 & 17.810 .12 & 7.870 .05 & $\begin{array}{ll}7.72 & 0.21 \\
\end{array}$ & 34.50 .02 \\
\hline & & Ns & $*$ & $* * *$ & $*$ & Ns & ns \\
\hline \multirow{9}{*}{ Plumage } & BLK+mottled & 1.360 .08 & $28.45^{\mathrm{a}} 0.52$ & $18.44^{\mathrm{abc}} 0.23$ & $8.85^{\mathrm{bc}} 0.15$ & 70.450 .51 & 33.70 .02 \\
\hline & WHT+mottle & 1.160 .06 & $27.60^{\mathrm{ab}} 1.02$ & $18.16^{\mathrm{bc}} 0.39$ & $8.30^{\text {bcd }} 0.30$ & 8.820 .18 & 36.40 .02 \\
\hline & BRN+mottled & $1.36 \quad 0.12$ & $27.62^{\mathrm{ab}} 0.50$ & $17.98^{\mathrm{bc}} 0.18$ & $8.95^{\mathrm{b}} 0.24$ & $8.16 \quad 0.47$ & 35.80 .02 \\
\hline & Black & 1.230 .03 & $27.39^{\mathrm{ab}} 0.65$ & $18.82^{\mathrm{abc}} 0.38$ & $8.27^{\text {cd }} 0.17$ & $7.32 \quad 0.75$ & 29.60 .03 \\
\hline & White & 1.110 .03 & $26.29^{b} 0.54$ & $17.64^{\mathrm{bc}} 0.27$ & $8.82^{\text {bcd }} 0.15$ & 9.330 .56 & 36.30 .02 \\
\hline & Brown & 1.110 .03 & $26.63^{\mathrm{ab}} 0.54$ & $17.48^{\mathrm{C}} \quad 0.20$ & $8.05^{\mathrm{d}} 0.10$ & 7.950 .55 & 30.10 .02 \\
\hline & Drkbrown & 1.240 .04 & $2658^{\mathrm{ab}} 0.39$ & $18.16^{\text {bc }} 0.20$ & $8.42^{\text {bcd }} 0.16$ & 7.200 .55 & 35.50 .05 \\
\hline & Drk red/golden & 1.400 .05 & $27.72^{\text {ab }} 0.43$ & $19.34^{\mathrm{a}} 0.26$ & $9.65^{\mathrm{a}} 0.12$ & $7.32 \quad 1.45$ & $\begin{array}{ll}75.7 & 1.48 \\
\end{array}$ \\
\hline & Ash & 1.200 .04 & $25.82^{\mathrm{b}} 0.18$ & $17.46^{\mathrm{C}} \quad 0.44$ & $8.97^{\mathrm{b}} 0.19$ & $7.06 \quad 0.76$ & 31.20 .04 \\
\hline \multirow[t]{7}{*}{ Eye colou } & & Ns & $* * *$ & $*$ & ns & ns & ns \\
\hline & DRK red & 1.310 .02 & $27.40^{\mathrm{b}} 0.29$ & 18.590 .21 & 8.770 .11 & 7.270 .36 & $36.0 \quad 0.04$ \\
\hline & DRK brn & 1.300 .05 & $26.85^{\mathrm{b}} 0.26$ & 18.130 .12 & $\begin{array}{ll}8.92 & 0.11\end{array}$ & $\begin{array}{ll}7.78 & 0.39\end{array}$ & 33.20 .01 \\
\hline & Pink & $\begin{array}{ll}1.13 & 0.07 \\
\end{array}$ & $33.33^{\mathrm{a}} 1.84$ & 19.330 .56 & $\begin{array}{ll}7.50 & 0.22 \\
\end{array}$ & $9.00 \quad 1.06$ & $\begin{array}{ll}38.3 & 0.05 \\
\end{array}$ \\
\hline & Light brown & 1.170 .02 & $26.64^{\mathrm{b}} 0.37$ & $17.90 \quad 0.18$ & $8.73 \quad 0.10$ & $8.28 \quad 0.42$ & $34.9 \quad 0.02$ \\
\hline & Light green & $\begin{array}{ll}1.18 & 0.12 \\
\end{array}$ & $35.67^{\mathrm{a}} 0.88$ & 18.110 .84 & 7.520 .81 & 8.250 .31 & $32.5 \quad 0.02$ \\
\hline & DRK ash & 1.130 .06 & $27.33^{\mathrm{b}} 0.18$ & $18.08 \quad 0.72$ & $8.58 \quad 0.20$ & 6.001 .58 & $25.0 \quad 0.06$ \\
\hline \multirow[t]{10}{*}{ Shank col } & & ns & $* * *$ & Ns & ns & Ns & ns \\
\hline & Milky & 1.230 .07 & $35.80^{\mathrm{a}} 0.80$ & $20.00 \quad 0.32$ & $8.00 \quad 0.00$ & $7.40 \quad 0.51$ & $33.0 \quad 0.03$ \\
\hline & Dark ash & 1.240 .02 & $27.18^{\text {cd }} 0.35$ & 18.420 .18 & $\begin{array}{ll}8.47 & 0.10 \\
\end{array}$ & $\begin{array}{ll}7.88 & 0.37\end{array}$ & $34.5 \quad 0.03$ \\
\hline & Ash & 1.230 .03 & $28.63^{\mathrm{bc}} 0.50$ & 18.140 .17 & $8.30 \quad 0.17$ & $\begin{array}{ll}7.98 & 0.34 \\
\end{array}$ & $32.6 \quad 0.01$ \\
\hline & Red & 1.200 .10 & $31.50^{\mathrm{ab}} 1.50$ & 20.25048 & $\begin{array}{ll}7.88 & 0.31 \\
\end{array}$ & 7.000 .00 & $28.3 \quad 0.02$ \\
\hline & light pink & 1.130 .16 & $28.25^{\mathrm{bcd}} 1.10$ & $18.00 \quad 0.85$ & $8.25 \quad 0.41$ & $8.50 \quad 0.87$ & $32.5 \quad 0.04$ \\
\hline & Light yellow & 1.130 .04 & $27.11^{\text {cd }} 0.53$ & 17.960 .25 & $8.88 \quad 0.61$ & 7.120 .90 & $\begin{array}{ll}29.5 & 0.03 \\
\end{array}$ \\
\hline & Pink & 1.130 .05 & $26.43^{\mathrm{d}} 0.57$ & 18.090 .17 & $9.03 \quad 0.10$ & $\begin{array}{ll}7.58 & 0.45\end{array}$ & $37.9 \quad 0.04$ \\
\hline & Ash- yellow & $\begin{array}{ll}1.57 & 0.18 \\
\end{array}$ & $28.92^{\mathrm{bc}} 1.16$ & $\begin{array}{ll}20.08 & 1.48 \\
\end{array}$ & 10.170 .42 & - & - \\
\hline & Yellow & 1.150 .08 & $25.15^{d} 0.95$ & $\begin{array}{ll}17.79 & 0.48\end{array}$ & $\begin{array}{ll}9.85 & 0.31\end{array}$ & - & - \\
\hline \multirow[t]{4}{*}{ Comb typ } & & ns & $* *$ & Ns & ns & Ns & ns \\
\hline & Single & $\begin{array}{ll}1.30 & 0.02\end{array}$ & $27.13^{\mathrm{b}} 0.18$ & 18.200 .09 & $8.75 \quad 0.06$ & $\begin{array}{lll}7.76 & 0.21 \\
\end{array}$ & $33.5 \quad 0.01$ \\
\hline & Rose & $\begin{array}{lll}1.40 & 0.08 \\
\end{array}$ & $29.93^{\mathrm{a}} 1.19$ & 18.570 .41 & $\begin{array}{ll}9.46 & 0.32 \\
\end{array}$ & $9.00 \quad 0.00$ & $30.0 \quad 0.00$ \\
\hline & Pea & 1.300 .30 & $29.00^{\mathrm{ab}} 1.00$ & 18.751 .75 & $8.25 \quad 0.75$ & 0.25 & - \\
\hline
\end{tabular}

abcd Means in a column within a subset with different superscripts are significantly differenct. Ns = not significant *=Significant @ 0.05**= significant @ $0.01 * * *=$ significant @ 0.001 DRK=dark, WHT=white, BRN/brn= brown, BLK=black, LW=live weight, BGirt=body girth, BL=body length, SHKL=shank length, CLuS=clutch size and Egg WT=egg weight 
Eye colour had considerable effect on body girth $(p<0.001)$ and length $(p<0.05)$ but did not in any way influence other body and egg measurements such as live weight, body length, shank length, clutch size and egg weight. Chickens with light green eyes had the widest body girth of $35.67 \mathrm{~cm}$. This was followed by chickens with pink eyes $(33.33 \mathrm{~cm})$ while dark brown and light brown eyed chickens had the least body girths of $26.64 \mathrm{~cm}$ and $26.85 \mathrm{~cm}$, respectively. Shank colour significantly $(p<0.001)$ affected body girth but had no such effect on other body and egg measurements. Birds with milky shanks had the highest body girth of $35.80 \mathrm{~cm}$, while the lowest value of $25.15 \mathrm{~cm}$ was recorded for chickens with yellow shanks. The effect of comb type was only significant $(p<0.01)$ on body girth. Rose combed chickens had the highest $(29.93 \mathrm{~cm})$ body girth followed by pea $(29.00 \mathrm{~cm})$ while single combed type had the least $(27.13 \mathrm{~cm})$.

Table 3 shows the means and standard errors of some egg measurements based on egg colour. The latter's effect was only detected on egg width $(P<0.001)$.Brown-shelled eggs were widest $(3.21 \mathrm{~cm})$ followed by those with white shells $(3.16 \mathrm{~cm})$, while light brown shelled eggs had the least $(3.13 \mathrm{~cm})$.
Correlation coefficients between body and egg measurements are presented in Table 4. The magnitude of the values of the parameters between body girth and length ( $r=0.527)$, and between body girth and live weight $(r=0.272)$ were positive and significant $(p<0.01)$. Similarly, the correlations between body length and live weight $(r=0.333)$ and, between body length and shank length $(r=0.423)$ were positive and considerable $(p<0.01)$. There was also positive and significant relationship between egg weight and clutch size $(r=0.291 ; p<0.01)$ and between shank length and body girth $(p<0.05)$. However, the correlations between shank length and clutch size and, between shank length and egg weight negative ( $r=-0.132, r=-0.147$, respectively) and still significant $(p<0.05)$.

Table 5 shows the correlation coefficients between some egg measurements. The values were positive and significant $(P<0.01)$ between egg weight and width $(r=0.838)$, between egg weight and length $(r=0.766)$, and between egg weight and shell weight $(r=0.244)$. Similar relationships also existed between egg width and length $(r=0.423)$, egg width and shell weight $(r=0.242)$ and between egg length and shell weight $(r=0.132)$.

Table 3: Means and standard errors of other egg measurements

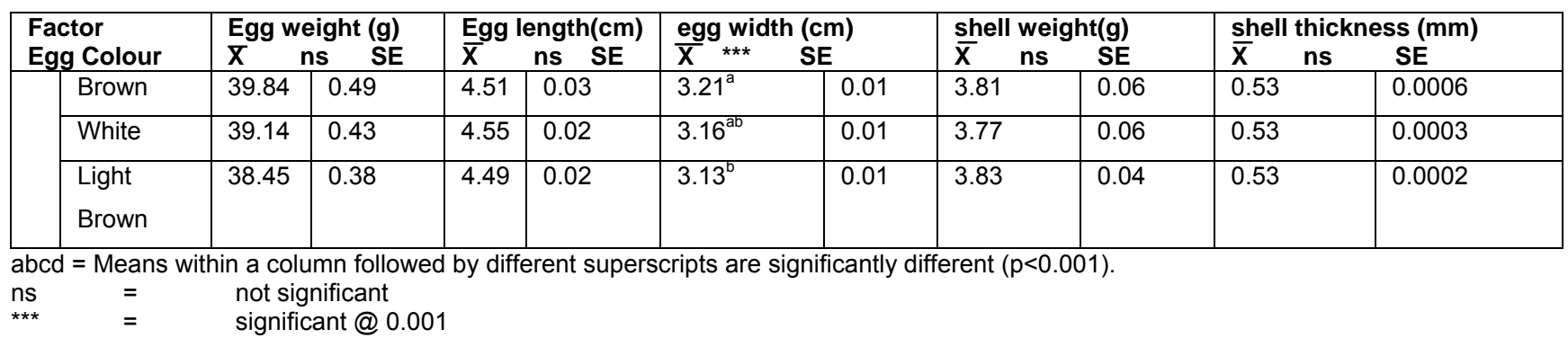

Table 4: Correlations between body and egg measurements

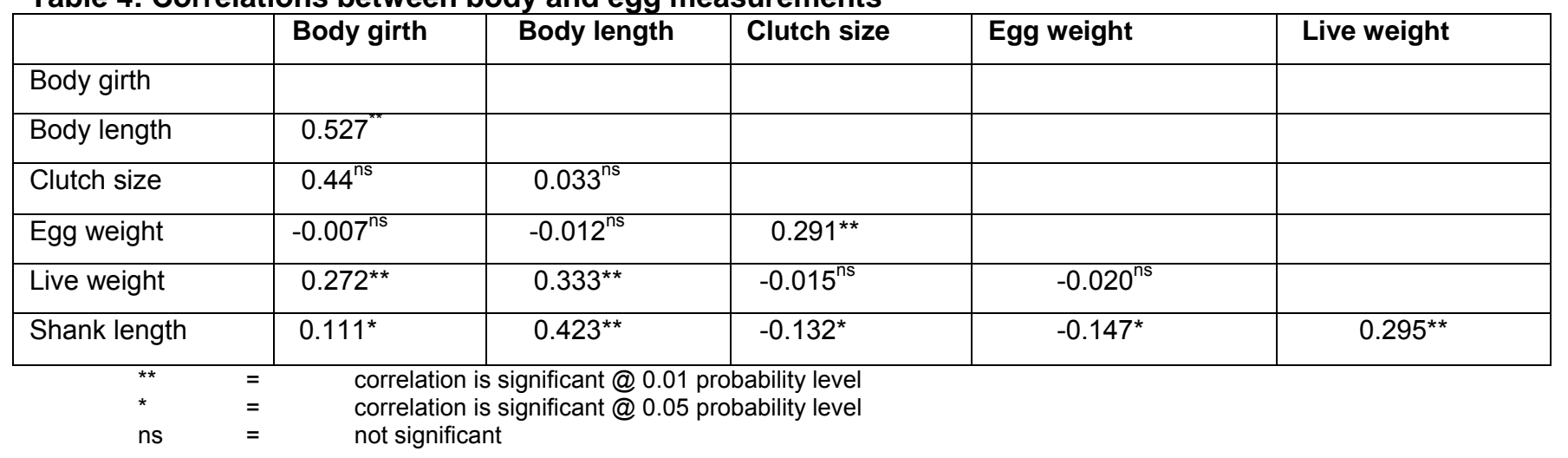


Table 5: correlation between egg measurements

\begin{tabular}{|l|c|c|c|c|}
\hline & $\begin{array}{l}\text { Egg } \\
\text { width }\end{array}$ & $\begin{array}{l}\text { Egg } \\
\text { length }\end{array}$ & $\begin{array}{l}\text { Egg } \\
\text { weight }\end{array}$ & $\begin{array}{l}\text { Shell } \\
\text { thickness }\end{array}$ \\
\hline Egg width & & & & \\
\hline $\begin{array}{l}\text { Egg } \\
\text { length }\end{array}$ & $0.423^{* *}$ & & & \\
\hline $\begin{array}{l}\text { Egg } \\
\text { weight }\end{array}$ & $0.838^{* *}$ & $0.766^{* *}$ & & \\
\hline $\begin{array}{l}\text { Shell } \\
\text { thickness }\end{array}$ & $0.093^{\text {ns }}$ & $-0.003^{\text {ns }}$ & $0.075^{\text {ns }}$ & \\
\hline $\begin{array}{l}\text { Shell } \\
\text { weight }\end{array}$ & $0.242^{* *}$ & $0.132^{*}$ & $0.244^{* *}$ & $-0.031^{\text {ns }}$ \\
$\begin{array}{l}* * \\
* \\
\text { ns }\end{array}$ \\
= significant @ 0.01 probability level \\
$=$ significant @ 0.05 probability level \\
=not significant
\end{tabular}

\section{DISCUSSION}

The purpose of keeping indigenous chickens at household level in the rural areas is mainly for consumption and income (Aini, 1990; Gueye, 1998; Moreki, 2000; Badubi et al., 2006). The observed differences in female/male ratio recorded with more females than males being kept for breeding were also observed in the reports of Mbap and Zakar (2000), Fayaye et al. (2006) and Sudik (2007).

Variation in phenotype is exactly what characterizes local chickens (Mc Ainsh et al., 2004). Badubi et al. (2006) in Botswana observed indigenous chickens to be multicoloured but predominantly black; others being brown, red, silver or metallic green in colour. Vietmeyer et al. (1991), Mbap and Zakar (2000) and Mancha (2004) reported similar observations. These reports are in agreement with those obtained in this study. The most probable explanation is that a number of genes interact to determine feather colours and patterns (Crawford, 1990) and probably because indigenous chickens have not been artificially selected (Oluyemi and Roberts, 1979).

That the dark brown, light brown and dark red are the most frequent eye colours found in the study area, is similar to reports of Mbap and Zakar (2000); Saidu (2002); Sudik (2007). Eye colour to a large extent depends on the pigmentation (carotenoid pigments and blood supply) of a number of structures within the eye (Crawford, 1990) On the contrary, however, Mancha (2004) reported orange eye colour as most common amongst indigenous chickens in Plateau State. That the commonest shank colours observed in the study were pink, dark ash, ash and light yellow is supported by reports of Mancha (2004) and Sudik (2007) in Plateau State. However, Oluyemi and Roberts (1979) had concluded that the commonest shank colours are yellow and black but other variants such as white, blue, slate and willow also exist.
These differences are probably the usual differences observed between and within free ranging local chickens in different geographical locations (Msoffe et al., 2002).Similarly, the fact that single combed chickens were predominant followed by those possessing rose and pea combs tallies with the reports of Oluyemi and Roberts (1979), Mbap and Zakar (2000), Ikeobi et al. (2001), Saidu (2002), Mancha (2004) and Sudik (2007) on indigenous chickens of Nigeria. Similar results were also obtained in other African countries; Badubi et al. (2006) reported that the indigenous chickens of Tanzania were mostly single combed as was also observed by Bhuiyan et al. (2006) in Asia among the indigenous chickens of Bangladesh. The higher values observed for the single comb type which was also the largest in size (Oluyemi and Roberts, 1979) suggests a selection advantage and greater adaptability. Combs are important avenue for heat loss in birds (Van Kampen, 1974) and since the tropical climate is characterized by high temperature (lbe, 1993), large combs would provide an efficient means for heat dissipation.

The light brown eggs were reported in this study area as being the most common. Bhuiyan et al. (2006) also reported similar findings amongst indigenous chickens of Bangladesh. This might be due to the fact that mating between white and brown-shelled populations usually results in intermediate colour between those of the parent stock (Hall, 1944). This was point can be buttressed by the fact that most indigenous chickens are kept with little or no controlled breeding (Horst, 1990 and Williams, 1990). However, Saidu (2002), Mancha (2004) and Sudik (2007) reported brown eggs as the most common..

Body weight is a function of frame or size and condition of animal (Philip, 1970). The average live weight of $1.3 \mathrm{~kg}$ reported in this study is comparable to those reported by Egbunike and Oluyemi (1979), Mancha (2004), Fayaye et al. (2006), Ezekwe et al. (2000) and Sudik (2007). Mopate and Lony (1999) reported similar average values in the local scavenging chickens of N'djamena, Chad. However, Mbap and Zakar (2000) reported a much higher value of $3.0 \mathrm{~kg}$ in Yobe, Nigeria. Badubi et al. (2006) reported differences in live weights among Botswana ecotypes. Similarly, Msoffe et al. (2002) recorded differences in local chickens among ecotypes of Tanzania. Aganga et al. (2000) and Badubi et al. (2006) attributed low live weight in indigenous chicken to poor management, while Mwalusanya et 
al. (2001) reported genetic, nutrition and parasitic problems as possible reasons.

The average body girth, body and shank lengths of local chickens in this study are comparable to those of Fayaye et al. (2006). This is in agreement with the fact that when chickens are taken as one group, their average values tend to mask the effect of individual region (Badubi et al., 2006).

The mean value of 7.86 eggs per clutch recorded in this study is similar to those reported by many authors (Wilson et al., 1987; Bulgen et al., 1992; Mopate and Lony, 1999; Missohou et al., 2002; Mapiye and Sibanda, 2005). The overall mean egg weight of $39.03 \mathrm{~g}$ recorded is also comparable to some reports in literature (Minga et al., 1989; Buldgen et al., 1992; Missohou et al., 2002; Msoffe et al., 2004). Most authors (Mbap and Zakar, 2000; Mancha, 2004; Sudik, 2007) in Nigeria however, observed deviation from the present study. This deviation may be due to differences in the genetics of the birds or type of management practiced (Maphosa et al., 2004).

That seasonal variation had significant effect on clutch size and the number of eggs laid were much more during the late wet than early dry or early wet seasons had been reported by Maphosa et al. (2004) and Mapiye and Sibanda (2005). The variation observed could be attributed to the feed availability (Tadelle et al.,2003; Maphosa et al., 2004). Similarly, the considerable variations observed between locations in terms of egg weight, live weight and body length should reflect differences in genetic constitution of subpopulations. The fact that live weight, body length and girth, and shank length also differed between sexes in favour of males has also been observed by many (Msoffe et al., 2004; Katule, 1990; Wilson et al., 1987) .Sexual dimorphism which is exhibited, especially at birth due to fetal hormones which promote higher skeletal growth in males (Awemu et al., 1999) and or longer gestation length in males (Ebozoje et al., 1995) is generally accepted as the main cause of this phenomenon. The fact that body length varied according to plumage type indicates that it is possible to use plumage colour to select for improvement in body length.

Many of the phenotypic correlations between body measurements and between body and egg measurements were positive and high. This fact has been reported (Mancha 2004; Sudik ,2007) The high and positive correlations between live weight and body girth, body length, and shank length indicate that in the absence of weighing facilities, measuring these traits using a simple tape could indicate live weight.

The high and positive correlations between shank length and body length, and body girth and body length are also indications that shank length and body girth could be used as indicators of body length. This is supported by the fact that most linear measurements reflect primarily the length of the long bones of animals (Oke et al., 2004; Hassan, 1993). Similarly, the positive correlation between body girth and shank length is also an indication that they could be used complimentarily in selection (Falconer, 1989). If the positive phenotypic correlations translate into positive genetic correlations thus, selection for one will improve the other as a correlated response (Muhiuddin, 1993). The results of this study are similar to reports by Mancha (2004) and Sudik (2007) in Plateau state. However the negative correlations between clutch size and shank length, and between egg weight and shank length are indications that shank length may not be suitable for improving both egg weight and clutch size. However, Sudik (2007) observed non significant correlations between clutch size and other body/egg characteristics.

That egg weight was significantly correlated with egg width, egg length and shell weight suggest that egg weight in local chickens could be predicted using these factors. Size of the hatching egg of broilers (and probably other chickens) influences body weight of chicks up to slaughter (Proudfoot and Hulan, 1981).Thus, physical characteristics of egg (width, length and shell weight) which play important role in the process of embryo development and successful hatching should be considered in selecting for improvement in live weight of the local chicken .

\section{CONCLUSIONS:}

The study has revealed that the local chickens could attain appreciable body and egg size characteristics. It is possible with further work to standardize the phenotypic characters observed and come up with some traits or values as characteristics of chickens in the area. Nonetheless, it can be stated in the interim that the indigenous chicken of Shelleng and Song Local Government areas were multicoloured, weighed $1.13-1.53 \mathrm{~kg}$, single combed, dark brown 
eyed, had pink shanks and laid $7-9$ eggs per clutch in three clutches per year.

\section{REFERENCES}

Aganga, A., Omphile, U., Malope, P., Chabanga, C., Motsamai, G. and Motsumi, L. (2000). Traditional poultry production and commercial broiler alternatives for smallholder farmers in Botswana. Livestock Research for Rural Development, 12: 1 - 8

Aini, I. (1990). Indigenous chicken production in SouthEast-Asia. World Poultry Science Journal, 46: 51 -57

Aliyara, Y. H. and Yakubu, B. (2000). Adamawa Livestock Industry. Pp 134 -202

Badubi, S. S., Rakereng, M. and Marumo, M. (2006). Morphological characteristics and food resources available for indigenous chickens in Botswana. Livestock Research for Rural development 16 (7)

Bhuiyan, A. K. F. H., Bhuiyan, M. S. A. and Deb, G. K. (2006). Indigenous chicken genetic resources in Bangladesh: current status and future outlook. Animal Genetic Resources Information. FAO corporate document repository 2 (11)

Buldgen, A., Detimmerman, F., Sall, B. and Compere, R. (1992). Etude desparameters demorphiques et zootechniques de la poule locale du basin arachidier Senegalais. Revue d' e'levage et de medicine veterinaire des pays tropicaux, 45 (3 - 4): 341 - 347

Chimbekujwo, B. I., Andenyang, F. I. H., Mshelia, S. I., Bristone, B., Dodo, J. D. and Saddiq, A.M. (2006). Baseline studies report in the three local government areas of Adamawa state:Local Empowerment and Environmental Management Project (LEEMP)

Crawford, R. D. (1990). Origin and History of Poultry Species. Poultry Breeding and Genetics (Crawford, R. D., Ed.). Elsevier, Amsterdam, The Netherlands, pp. 1 -42 .

Ebozoje, M. O., Ngere, L. O. and Nwosu, I. C. (1995). An analysis of preweaning. Body weights in West African Dwarf goats and their crosses. Nigerian Journal of Animal Production 22 (2): 125 - 129.

Egbunike, G. N. and Oluyemi, J. A. (1979). Comparative studies of the reproductive capacity of Nigerian and Exotic poultry breeds. 1. Testis and semen characteristics. Nigerian Journal of Animal Production $6,(1 \& 2)$

Ekeren, N. U., Maas, A., Scatkamp, A. W., Verschuur, M. (1990). Small Scale Poultry Production Wageningen, Netherlands.

Ezekwe, A. G., Udeozor, I. J. and Osita, C. O. (2000). Effects of Quantitative Feed Restriction On the Semen Quality of Nigerian Local Cocks. Proceedings of $5^{\text {th }}$ Annual Conference of Animal Science Association of Nigeria, Port Harcourt, Nigeria

Falconer, D. S. (1989). Introduction to Quantitative Genetics. $3^{\text {rd }}$ Edition, Longman, London. Pp. 438.
Fayaye, T. R., Ayorinde, K. L., Ojo, V., and Adesina, O. M. (2006). Frequency and influence of some major genes on body weight and body size parameters of Nigerian Local Chickens. Livestock Research for Rural Development 18(3)

Gambo, Y. M. (2002). The minerals of Northern Nigeria: Goldmine Underutilized. Paraclete publishers, Yola, Nigeria. Pp 88 - 89.

Gueye, E. F. (1998). Village egg and fowl meat production in Africa. World Poultry Science Journal 54: 73 -86

Gueye, E. F. and Hooft, Van't, K. (2002). Networking for family poultry development. LEISA, Vol. 1, (4) pp 36

Hassan, H. A. (1993). Crossbreeding between some poultry strains for meat production. National Animal Production Research Institute (NAPPRI). Pp 157

Horst, P. (1990). Research development perspectives. In: $U$ Riest (editor), CTA-seminar proceedings: Smallholder Rural Poultry Production, Thessalonki, Greece, 9 - 13

Ibe, S. N. (1993). Growth performance of normal, frizzle and naked neck chickens in tropical environment. Nigerian Journal of Animal Production. 20: 25 - 31

Ikeobi, C. O. N., Ozoje, M. O., Adebambo, O. A. and Adenowo, J. A. (2001). Frequencies of Feet Feathering and Comb Type Genes in the Nigerian Local Chicken. Pertanika Journal for Tropical Agricultural Science. 24: 147 -150

Katule, A. M. (1990). Studies on the prospects of improving the performance of local chicken populations in Tanzania by crossbreeding. Unpublished Thesis for the award of PhD Degree at Sokoine University of Agriculture

Kitalyi, A. J. (1998). Village chicken production systems in rural Africa household Food security and gender issues. FAO, Rome

Mancha, Y. P. (2004). Characterization of local chickens in Northern part of the Jos Plateau. A PhD Thesis, Animal Production Programme, School of Agriculture, ATBU, Bauchi.

Maphosa, T., Kusina, N. T., Makuza, S. and Sibanda, S. (2004). A monitoring body comparing production of village chickens between communal (Nharira) and small scale commercial (Lancashire) farming areas in Zimbabwe. Livestock Research for Rural Development 16 (7)

Mapiye, C. and Sibanda, S. (2005). Constraints and opportunities of village chicken Production systems in the smallholder sector of Rushinga district of Zimbabwe. Livestock Research for Rural Development $17(10)$

Mbap, S. T. (1985). The Performance of Local, Exotic and Hybrid Cattle at Ibadan and Vom in Nigeria. Ph.D. Thesis, University of Ibadan, Ibadan.

Mbap, S.T. and Zakar, H. (2000). Characterization of local chickens in Yobe state, Nigeria. In: (B) The role of 
Agriculture in Poultry in Poverty Alleviation. Editors: Abubakar, M.M, Adegbola, T.A. and Butswat, T.S.R.) Proceedings of the $34^{\text {th }}$ Annual Conference of the Agricultural Society of Nigeria (ASCN) October 15-19, 2000, Bauchi. 126-131.

McAinsh, C. V., Kusina, J., Madsen, J. and Nyoni, O. (2004). Traditional chicken production in Zimbabwe. Worlds Poultry Science Journal, 60: 233 - 246

Minga, U. M., Katule, A., Maeda, T. and Musasa,. (1989). Potentials and problems of the traditional chicken industry in Tanzania. In: proceedings of the $7^{\text {th }}$ Tanzania Veterinary Association Scientific Conference, p $207-215$

Misssohou, A., Dieye, P. N. and Talaki, E. (2002). Rural poultry production and productivity in southern Senegal. Livestock Research for Rural Development 14 (2)

Mopate, L. Y. and Lony, M. (1999). Survey on family chicken farms in the rural area of N'Djamena, Chad. Livestock Research for Rural Development (11)2

Moreki, J. C. (2000). Village poultry production in fifteen villages of Botswana: Phase 1 (surveys) of the Poultry Development Project, AG. 205 (51/205). Department of Animal Health and Production, Gaborone, Botswana. 61p.

Msoffe, P. L. M., Mtambo, M. M. M. Minga, U. M., Gwakisa, P. S. Mdegela, R. S. and Olsen, J.E. (2002). Productivity of natural disease resistance potential of free-ranging local chicken ecotypes in Tanzania. Livestock Research for Rural Development, 14 (3) http://www.cipav.org. co.//rrd//rrd 14/3/msof 143.htm

Msoffe, P. L. M., Mtambo, M. M. M., Minga, U. M., Olsen, J. E., Juu-IMadsen, H. R., Gwakisa, P. S., Mutayoba, S. K. and Katule, A. M. (2004). Productivity and reproductive performance Of the free-ranging local domestic fowl ecotypes in Tanzania. Livestock Research for Rural Development 16: 9

Muhiuddin, G. (1993). Estimates of genetic and phenotypic parameters of some Performance traits in beef cattle. Animal Breeding Abstracts. 66: 495 522.

Mwalusanya, N. A., Katule, A. M., Mutayoba, M. M. A., Olsen, J. E. and Minga, U. M. (2001). Productivity of local chickens under village management conditions. Tropical Animal Health and Production, 34: 405 - 416

Oke, U. K., Herbert, U. and Nwachukwu, E. N. (2004). Association between weight and some egg production traits in the guinea fowl (Numida meleagris galeata. Pallas). Livestock Research for Rural Development 16 (9).

Oluyemi, J. A. and Roberts, F. A. (1979). In: poultry production in warm and wet climates. Edited by Oluyemi J. A. and Roberts, F. A. The Macmillan Press Ltd. London and Basingstoke

Philip, J. S. (1970). Poultry Feeds and Nutrition. The Avi publishing co. Inc., West Port Connection U S A.

Proudfoot, F. G. and Hulan, H. W. (1981). The influence of hatching egg size on the subsequent performance of broiler chickens. Poultry Science Journal 60: 2530 2541

Roberts, J. A. (1995). Assessing the scavenging feed resource base for sustainable Smallholder poultry development. Proceedings ANRPD workshop, Addis Ababa, Ethiopia. Pp $40-52$.

Saidu, I, A. (2002). Characterization of Local Chickens in Bauchi: PGD Desertion, Animal Production Programme, Abubakar Tafawa Ballewa University Bauchi.

SPSS.(1996). Statistical Package for Social Sciences. SPSS Users guide 10.0. SAS Institute Inc. Cary NC

Sudik, S.D. (2007). Characterization of local chickens in Plateau State, Southern Zone. An Msc Theses. Animal Production Programme, School of Agriculture, ATBU, Bauchi.

Tadelle, D., Million, T., Alemu, Y. and Peters, K. J. (2003). Village chicken production systems in Ethiopia: 2. Use patterns and performance valuation and chicken products and socio-economic functions of chicken. Livestock Research for Rural Development 15 (1).

Van Kampen, M. (1974). Physical Factors Affecting Energy Expenditure. In Energy Requirements of poultry eds. T.R. Morris and B. M. Freeman. Edinburgh British Poultry Science Ltd.

Vietmeyer, N. D. (1991). Micro livestock: Little-known Small Animals with a Promising Economic Future. National Academy Press, Washington, D. C.

Williams, G. E. S. (1990). Smallholder rural poultry production in Ghana. In: $U$ Riest (editor), CTAseminar proceedings, Smallholder Rural Poultry Production, 9 - 13

Wilson, R. T., Traore, A., Kuit, H.G. and Slingerland, M. (1987). Livestock production in central Mali: reproduction, growth and mortality of domestic fowl under traditional management. Tropical Animal Health and Production, 19: 229 - 236. 